\title{
H.M.S. BEAGLE IN TASMANIAN WATERS
}

\author{
by Peter Charles Stevenson
}

(with two text-figures, one plate and 11 tables)

\begin{abstract}
Stevenson, P.C. 2009(11:xii): H.M.S. Beagle in Tasmanian waters. Papers and Proceedings of the Royal Society of Tasmania 143(2): $105-116$. https://doi.org/10.26749/rstpp.143.2.105 ISSN 0080-4703. 2/3 Yolla Street, Rose Bay, Tasmania 7015, Australia. Email:psteve4@bigpond.com

A photocopy of the log of H.M.S. Beagle from 1-22 February 1836 was examined and a transcription made from the handwritten script. The import of the column headings is explained, and comments are made on the course, navigation, the winds encountered, the weather,

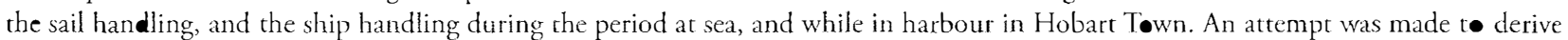
the synoptic weather situation.
\end{abstract}

Key Words: Beagle, FitzRoy, Darwin, Hobart Town, sail handling, ship handling, Charles Darwin.

\section{INTRODUCTION}

Between December 1831 and October 1836 H.M.S. Beagle made her second voyage to South America and around the wørld. The voyage was $\bullet$ ccasioned by the recent revølutions in the former Spanish colonies in Søuth America which had $\bullet$ pened them up t• trade, and the British Admiralty

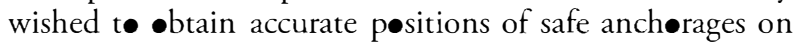
the inhospitable coasts.

The Beagle was a barque of 242 tøns specially equipped

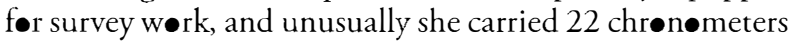

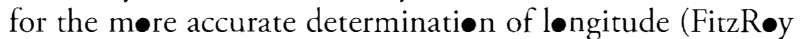
1839). On the recommendation of her commander,

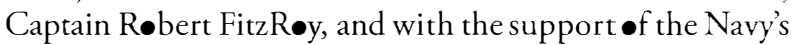
Hydrøgrapher, Admiral Francis Beaufort, she carried a naturalist tø recerd the natural histery of the parts visited. The naturalist was an inexperienced amateur in his early twenties, Charles Darwin, whe paid for the passage of himself and his servants. Darwin $(1839 \mathrm{a}, \mathrm{b})$ recorded his -bservations and, with special reference t• Tasmania, his observatiøns have been extended in Davies (2009).

\section{MATERIALS AND METHODS}

Phot copies of the $\log \bullet$ H.M.S. Beagle were $\bullet$ btained frøm the Public Record Office, now The National Archives, Kew, in 2000. The Beagle log for the entire five years of the Secønd Voyage, when Charles Darwin was $\bullet$ b bard, appears in the recerds as AD 53/236. The peried covered by the copies examined here was $1-22$ February 1836 . The løgs are handwritten and there is little variation in the script. The

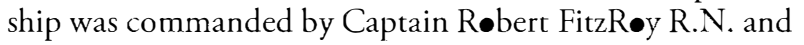

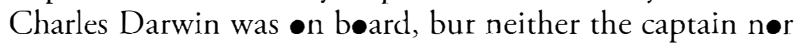
Charles Darwin figure in the $\log$. Four watch •fficers are identified, and the løg appears tø have been kept by Edward Chaffers, the Master.

\section{DAY TABLES}

\section{General remarks}

The Day Table is the unit $\bullet$ the $\log$. Each cøvers 24 hours, is handwritten, and appears to be drawn up in to columns with notations for each day. The handwriting døes not appear to change, as one might expect, and I interpret that the løg was kept by the Master, Edward Chaffers. The Master usually kept a second copy of the log, and his copy has been used før the periød 5-6-7 February. The handwriting is similar in this decument.

The left-hand columns headed $H, K$ and $S$ are in accerdance with Admiral Beaufort's "instructiøns" (FitzRoy 1839, pp. 32-42), and signify the Høur, the Speed in Kn॰ts, and possibly the state $\bullet$ the Sea, or the Swell. Enquiry $\bullet$ the Research Section $\bullet$ the Meteørøløical Office, Exeter, UK, elicited the response that they cøuld nøt interpret this latter column heading.

The Course column which follows is indicated in

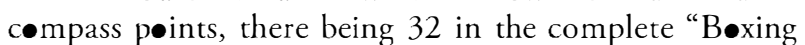
of the Compass". Half points are used occasionally. The abbreviation "b" as in SbW indicates "by", and is given by a very small superscript " $b$ ". The Winds column uses the same cempass conventiens, and "Wly" indicates "Westerly".

There follows the Wind Force using Admiral Beaufort's Wind Scale, and the Weather column using the admiral's Weather Letters, and appearing in the "Hydrographer's Instructiøns" (FitzRøy 1839, pp. 40-41). There appears to be an added "a" to the letters, n七t recognised in the Instructions. The letter is quite clear and is often used, but

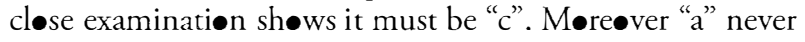
occurs with "c". The letter "q", indicating squalls appears -ften, thøugh it can be cønfused with "g". Squalls were regarded with søme fear, sometimes described by Captain FitzRøy as "pamperos" (FitzRoy 1839, pp. 85-89), and in view of the reputation amongst the crews of the Cherokee Class ships t• which Beagle belønged, as a "Cøffin Ship" (Geddie 1959), this was perhaps wise.

Then follows the Sympiesømeter column. This early air barømeter was preferred by Captain FitzRoy as being less fragile and handier than a mercury barømeter, as well as affording an Air Temperature reading in Fahrenheit degrees as well as pressure. The Air Temperature had to be used as a correction before the air pressure could be determined. The figure given in the column is usually a decimal part of an inch, the whole number having been indicated earlier in the Day Tables. The Air Temperature follows. The next column poses a problem. The heading is very poorly written, but seems t• be something like "Lee Sig". The column entries clearly are the initials of the Officer of the Watch, and appear two or three times in each 12-hour periød. All of the initials have been recognised from the crew list. 
Only four officers are involved in the records from Tasmanian waters: Peter Benson Stewart (PBS), the Mate; Edward Main Chaffers (EMC), the Master; Arthur Mellersh (AM), Midshipman and Mate from 1832; and, once, Charles Richard Johnson (CRJ), Mate.

Lastly follows the Remarks column. The ship's title is sometimes rendered "HMS" and sometimes as "H.M.S." Headed either AM or PM for the two halves of the day, the Remarks give details of the sail handling which are dealt with later in this paper. There are two Azimuth observations of the Sun on 21 and 22 February 1836, the first of the setting sun and the second of the rising sun. These observations use the Sun's declination for the day of the year and the ship's known latitude, where from Azimuth Tables the true bearing of the Sun can be derived (Norie 1943) - a very useful check on the magnetic compass in strange waters.

At midday on each page, a summary of progress is given including a consolidated Course and Distance covered, in Nautical Miles, a Dead Reckoning and Observed Position in Latitude and Longitude, in the form "143.53" not using degree and minute symbols. Then follows a Bearing and Distance to some prominent known point on the charts, presumably given from the midday fix, even though often the known point is not visible.

Thereafter the Day Table continues, without repeating the original column headings.

The log pages are in pairs, so that, for instance, 21 and 22 February appear on the same sheet. The day of the week is usually given, but 1836 does not always appear.

The positions of the Noon Sights are given in figure 1. All but two are astronomical, observed usually by extra-meridian altitudes of the Sun, giving both latitude and longitude; but overcast weather necessitates dead reckoning, using distances and directions from the last known position. There is no indication that the other methods of celestial navigation, ordered by the Hydrographer, were used (FitzRoy 1839). Where land is near, navigation is by land sights.

The names of sails are given in figure 2 . Where the reading is not clear a query (?) is inserted. Transcription of the Day Tables is provided in tables $1-11$, and an interpretation of each table is provided.
H.M.S. Beagle left Sydney on 30 January 1836 and on 1 February was making good steady progress down rhe East Coast of Tasmania before a northerly wind of force 6 (table 1). The wind was such that studdingsails were taken in during the early morning and the ship was making 8 knots. The morning weather was logged as "blue sky, cloud, mist" later changing to "overcast, cloud, mist, passing showers". A course alteration at 4 am was noted by Peter Benson Stewart. It was a warm day at $69 \mathrm{~F}^{\circ}$ but cooling.

At midday only dead reckoning position was given, possibly due to the overcast sky, and a direction and distance given to Cape Pillar. The weather deteriorated further after noon, becoming gloomy, and the wind backed to northwesterly and strengthened, so reefing became necessary, force 10 being logged, and the sea state worsened temporarily. Later, however, the wind dropped to force $6-7$, and by 8 pm the ship's speed had dropped to 6 knots, the sea state had reduced, but possible squalls were logged. Fore staysail and fore trysail were set and reefs cleared. By midnight, the ship was making 7 knots and the sea state was easy.

On 2 February, the wind was round to west-northwest by early morning, the weather was still gloomy but main and fore courses were set (table 2). At 5 am a remark was lefr incomplere, but by 7 am, reefs were shaken out with the wind at force 7 , and at $10 \mathrm{am}$, royals and studdingsails were all set. The wind was dropping away but the sea state rising a little. Weather reported as "blue sky, cloud, good visibility". Land was seen at 9 am and again at noon.

The noon sight gave a dead reckoning and an observed position, and Cape Pillar was now 90 miles off. Peter Benson Stewart was the Officer of the Day.

The wind dropped to force 2 by afternoon and the speed to 4 knots. A course alteration towards the land was made at $2 \mathrm{pm}$, a ship was seen, spanker and gaff topsail were set to make good use of the slight wind, but soon reefs were put in and the jib and spanker taken in, possibly because the wind had gone round to the southwest. Towards evening, "blue sky, cloud, gloomy, and passing showers" were recorded. By $10 \mathrm{pm}$, the wind having dropped further, topgallants, jib and spanker were reset. The barometer was unsteady, the weather still gloomy and the sea state rising. About this

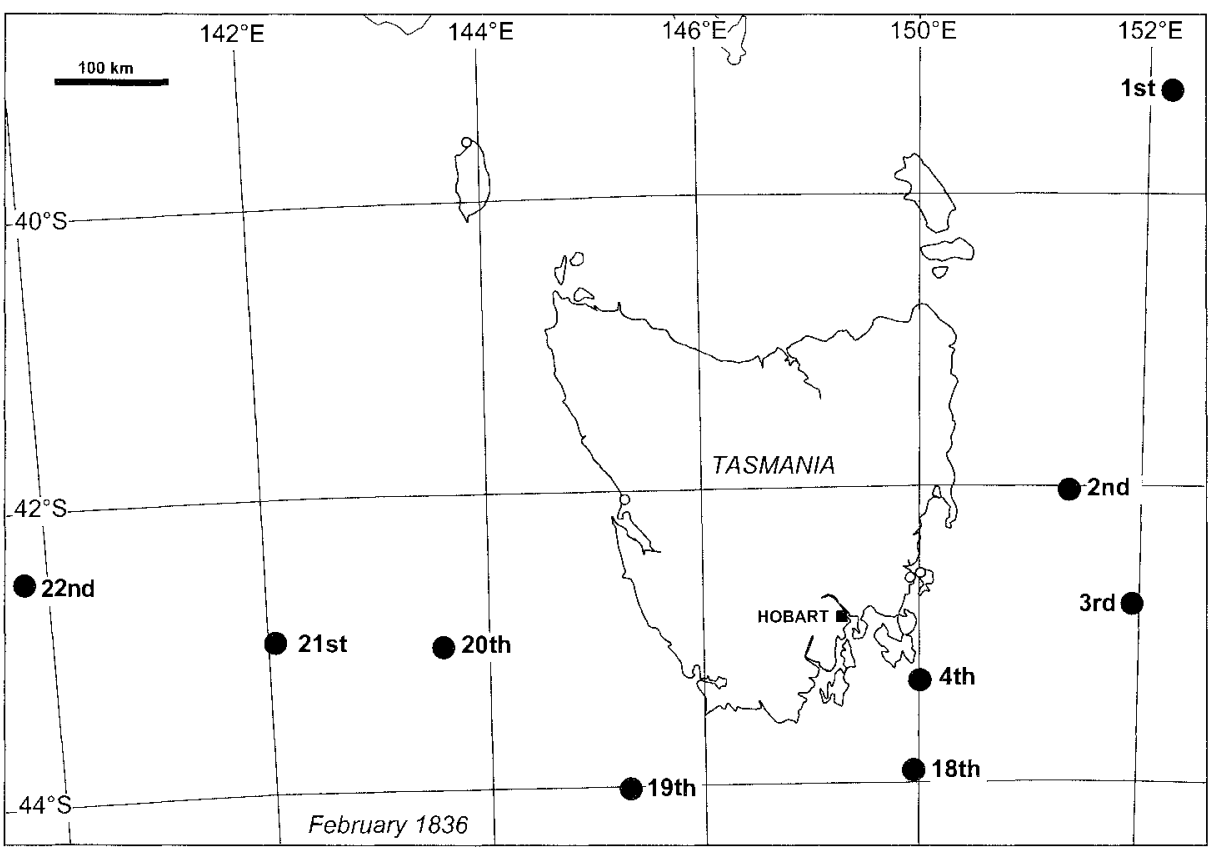

FIG. 1 - Positions of the noon sights 
time, Charles Darwin complained that the weather was "very cold and squally" (Darwin 1839b, p. 532), but as a poor sailor this may have been an exaggeration.

On 3 February, the wind had veered to west by south at force 5, with "blue sky, overcast, (sic), gloomy, fog" (table $3)$. The course was now towards the southeast, then with failing wind, (force 2), to east by south. Reefs were taken out and the gaff topsail set. These were taken aback by a wind change and a risk of squalls; two reefs were taken in topsails, jib and spanker. The speed was now slow, 1-2 knots, and the wind variable. Wore ship, [by turning the ship through a large angle away from the wind instead of a small angle through the wind], to change tack, then set topgallants, jib and spanker, which were taken aback again in force 4 winds. Finally royals and flying jib were set, as if in defiance.

It must have been very trying. A detailed course can be constructed from the log, which shows that the ship was sailing north some of the time, but the inherent inaccuracies of this process show that an accurate plot is barely possible.

The noon position was given as 85 miles from Cape Pillar. The course was now southwest by south, a close-hauled course with the wind westerly. In force 2 winds studdingsails were set, but only to be taken in later with rising wind. Many course changes occurred in changing winds, but the wind was now veering to north northwest, and a course was taken to the southwest with spanker and gaff topsail set. The barometer was falling to 30 inches and below. Again Peter Benson Stewart was the Officer.
On 4 February, the sail was reduced and reefs put in as the ship was close-hauled five points off the wind (table 4). Jib and spanker, useful in this condition, were taken in and then reset. Topgallants were set and then taken in, but, with failing wind, reefs were taken out. Land was sighted; Cape Pillar, Tasman Head and Cape Raoul were identified and with the wind veering to north-northwest, royals and flying jib were set but soon struck. The weather was overcast and rainy with a hint of squalls.

There was no noon sight. In failing and variable wind, there were many course changes, with speed at 2 knots and continued fear of squalls. Tacking and a difficult work to windward occurred, with reefs to topsail, and main, jib and spanker struck. Bearings to Cape Pillar and Cape Raoul give running fixes, but rising wind split the fore topmast staysail and required the bending on of another. Anomalous half entries in the Signature column are of unknown significance. Again Peter Benson Stewart and briefly Charles Richardson Johnson were the signing Officers.

The description covering 5-7 February 1836 is taken from the Master's log (table 5).

With the wind northerly at force 6 , and again with a hint of squalls, wore ship to change tack, and jib, spanker and topgallants were set. A running fix from the Capes was taken, and by 8 am reefs were taken out. The weather was overcast with some blue sky but gloomy, with squalls and passing showers. This day must be that referred to by Charles Darwin when he said that "the weather justified this awful name" of Storm Bay (Darwin 1839b, p. 532).

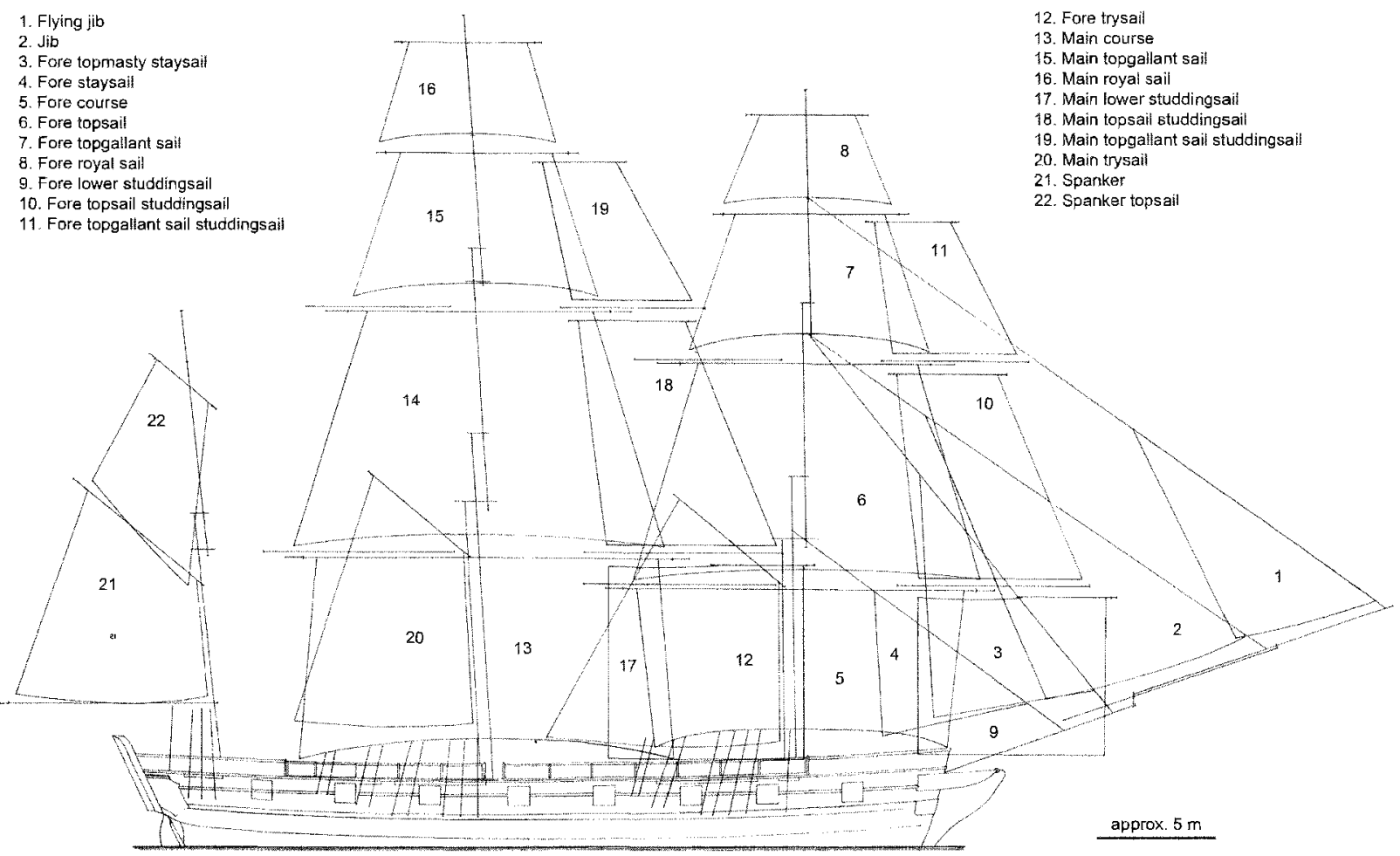

FIG. 2 - Sails carried on H.M.S. Beagle. (After Marquardt, K.H. 1997: Anatomy of the Ship HMS Beagle Survey Ship Extraordinary. Conway, Anova Books Ltd, London: 128 pp.) 


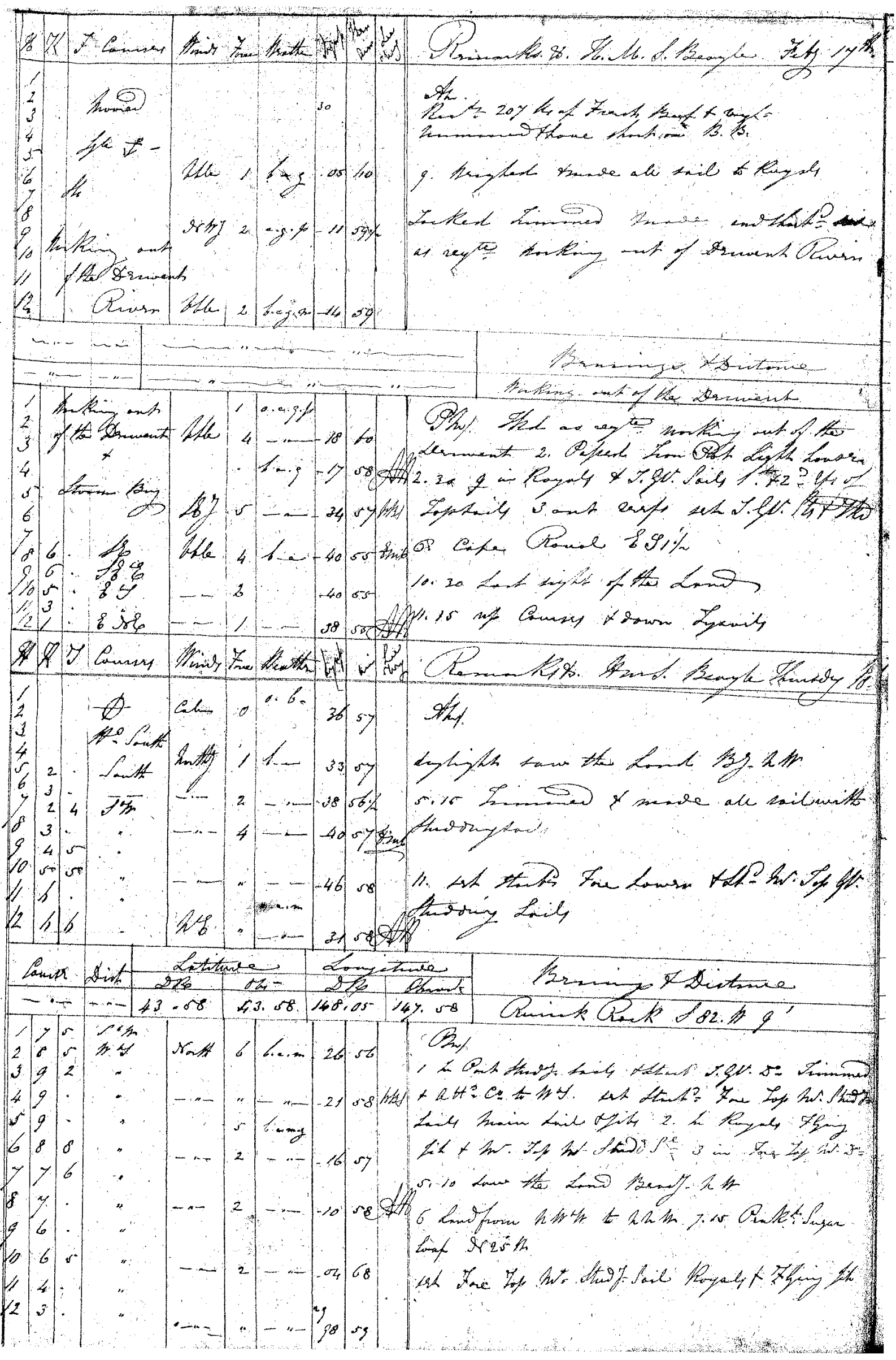


TABLE 1

Day Table of the log of H.M.S. Beagle for 1 February 1836

$\mathrm{H}=$ Hour; $\mathrm{K}=$ Speed in Knots; $\mathrm{S}=$ ? State of the sea or Swell; Course, measured in compass points, there being 32 in the complete "Boxing of the Compass": $b=$ by: Wly = westerly: Wind Force measured by Admiral Beaufort's Scale; Weather, recorded as Beaufort's weather Letters in FitzRoy 1839, pp. 40-4l; q = squalls; Sympiesometer = barometric pressure; Air Temperature in degrees Fahrenheit; Lee Sig = ? initials of the Officer of the Watch.

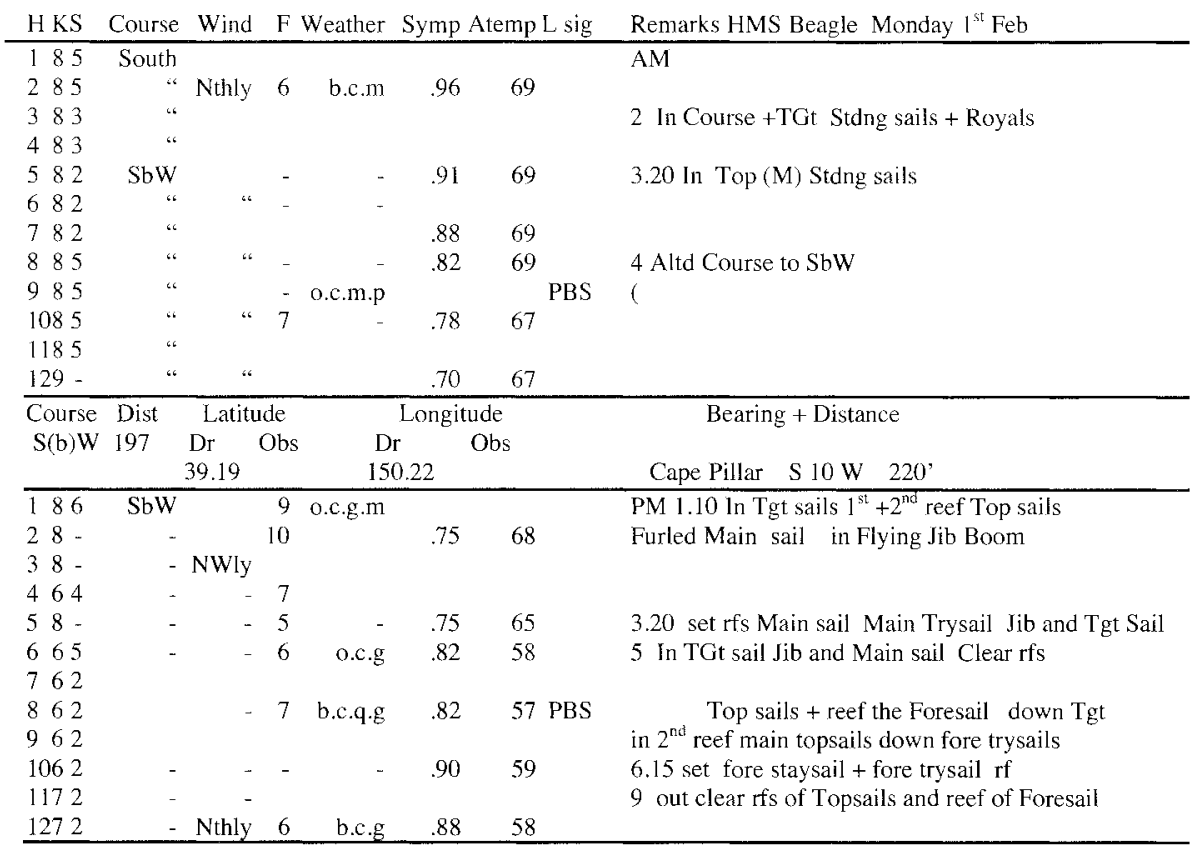

TABLE 2

Day Table of the log of H.M.S. Beagle for 2 February 1836

$\mathrm{H}=$ Hour; $\mathrm{K}=$ Speed in Knots; $\mathrm{S}=$ ? State of the sea or Swell; Course, measured in compass points, there being 32 in the complete "Boxing of the Compass"; $b=$ by; Wly = westerly; Wind Force measured by Admiral Beaufort's Scale; Weather, recorded as Beaufort's weather Letters in FitzRoy 1839, pp. 40-41; q = squalls; Sympiesometer $=$ barometric pressure; Air Temperature in degrees Fahrenheit; Lee Sig $=$ ? initials of the Officer

\begin{tabular}{|c|c|c|c|c|c|c|c|c|}
\hline HKS & Course & Wind & $\mathrm{F}$ & Weather & Symp & Air & $* *$ & Remarks to HMS Beagle Tuesday $2^{\text {nd }}$ \\
\hline $18-$ & SbW & & & & & & & \\
\hline $28-$ & & WNW & 7 & b.c.g & .89 & 57 & & AM 2 up Main sails + up the Foresail \\
\hline $37-$ & - & & 8 & & & & & \\
\hline $47-$ & - & - & 9 & - & .90 & 57 & & 5 set \\
\hline $57-$ & & & 8 & & & & & \\
\hline $67-$ & - & - & - & - & .92 & 56 & & \\
\hline 774 & - & & & & & & & 7 out $3^{\text {rd }}$ rf of Topsails 8 crossed Tgt yds out rf \\
\hline 874 & - & - & 7 & - & .94 & 56 & & of Mainsl \& Trysl, set Jib \& Tgt sail 8.30 out \\
\hline $97-$ & - & - & - & - & - & - & & $2^{\text {nd }} \mathrm{rfs}$ Obs land on $\mathrm{W}$ beam 9 out all ifs \\
\hline 1065 & - & - & 5 & b.c.v & .92 & 56 & & 10 set Starbd Top M Stdngsails 10.40 set Royals \\
\hline $116-$ & - & & & & & & & Flying \& T.Gt Studding sails \\
\hline 1256 & - & - & 4 & - & .88 & 56 & PBS & 12 Extremes of land WbS \& WbS to $S$ \\
\hline \multirow[t]{2}{*}{$\overline{\text { Course }}$} & Dist & \multicolumn{3}{|c|}{ Latitude } & \multicolumn{2}{|c|}{ Longitude } & & Bearing and Distance \\
\hline & & Dr & & Obs & Dr & Obs & & \\
\hline S by $W$ & 169 & \multicolumn{2}{|c|}{$41-56$} & $42-01$ & $149-11$ & \multicolumn{2}{|c|}{$149-21$} & Cape Pillar S45W dist $90^{\prime}$ \\
\hline 165 & SW & NWly & & & & & & \\
\hline $21 / 28$ & SWbS & NWly & 2 & b.c & .87 & 60 & & PM 2.15 altd course Trimmed sails set Spanker \\
\hline 335 & - & & & & & & & \& gaff topsl Obs a ship on lee beam standing to North \\
\hline $44-$ & - & - & 2 & b.c.g & .91 & 59 & & 4.30 in Tgt sails and Gaff Topsl $1^{\text {st }} \& 2^{\text {nd }}$ rfs of Topsls \\
\hline 545 & SEbS & SW & 4 & o.c.g.p & & & & \\
\hline 64 & - & & & - & .84 & 57 & & 7.20 down Jib \& Spanker in 1st if Mainsails \\
\hline 745 & SE & & & & & & & 10 set Tgt Sails Jib and Spanker \\
\hline 845 & - & - & 6 & b.c.g.p & .92 & 55 & $\%$ & \\
\hline 945 & - & & & & & & & 11.30 in Ditto \\
\hline 1042 & - & SSW & 5 & b.o.v & .94 & 55 & & \\
\hline 1156 & - & & & & & & & \\
\hline 1255 & & - & - & b.o.g & .85 & 55 & PBS & \\
\hline
\end{tabular}


TABLE 3

Day Table of the $\log$ of H.M.S. Beagle for 3 February 1836

$\mathrm{H}=$ Hour; $\mathrm{K}=$ Speed in Knots; $\mathrm{S}=$ ? State of the sea or Swell; Course, measured in compass points, there being

32 in the complete "Boxing of the Compass": $b=b y:$ Wly $=$ westerfy: Wind Force measured by Admiral

Beaufort's Scale: Weather, recorded as Beaufort's weather Letters in FitzRoy 1839, pp. 40-41; $q=$ squalls;

Sympiesometer = barometric pressure; Air Temperature in degrees Fahrenheit; Lee Sig = ? initials of the Officer of the Watch.

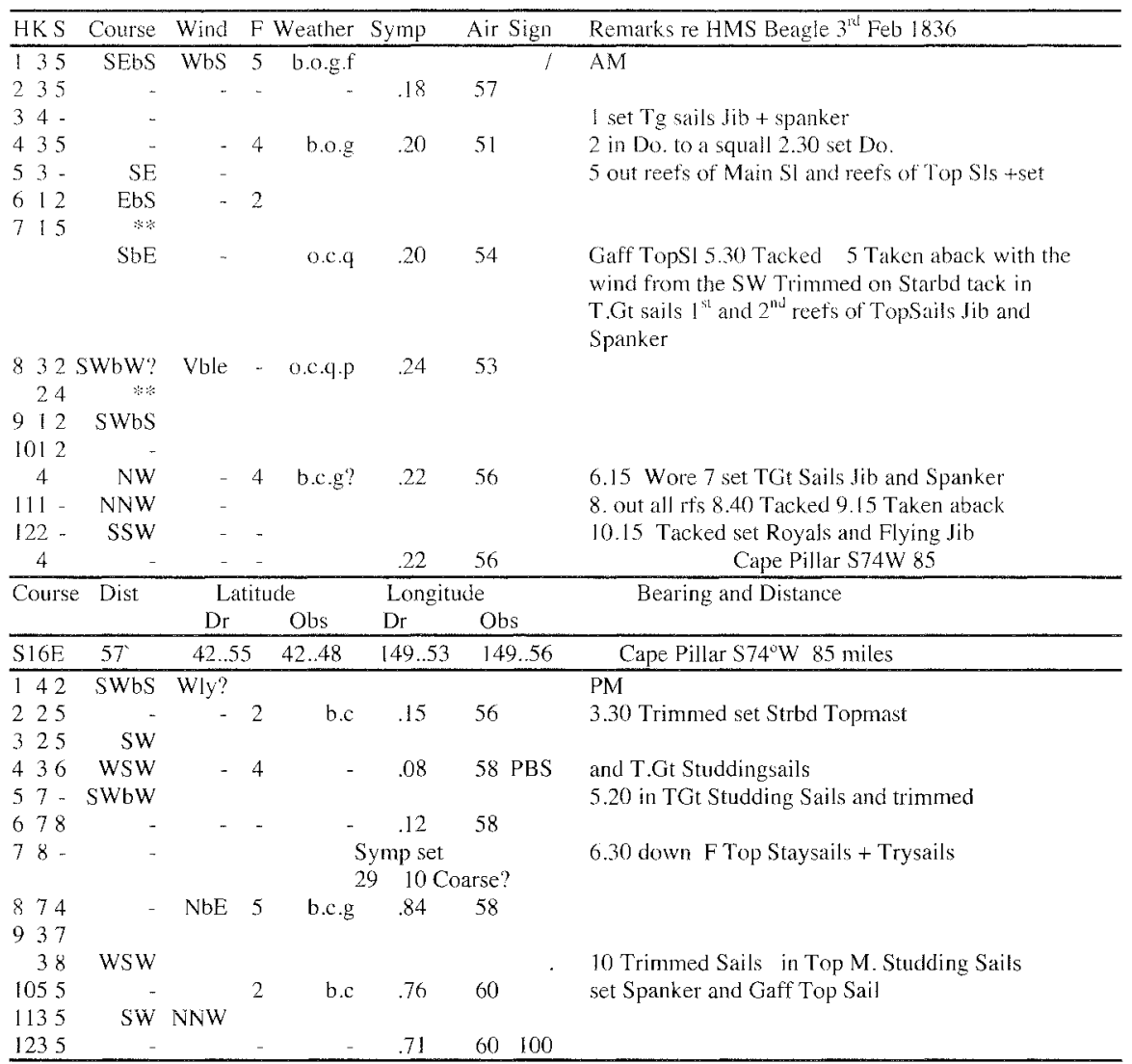

There was no noon sight as land was close, and the rest of the day was given as "working up Storm Bay and standing up the Derwent". The lighthouse at the Iron Pot was noted at $2.20 \mathrm{pm}$.

Wind was variable, and short sail was made "as requisite to squalls". Such sharp capfuls of wind are very common in summer as the air drains off Mount Wellington, and to this day catches ships, large and small, unawares.

Sullivans Cove was entered at $6.40 \mathrm{pm}$, and mooring was completed with 30 fathoms of cable from bow and stern. H.M.S. Beagle was moored in the cove but not laid alongside, there being no established wharf. The expression "B.B." appears, and is taken to mean Best Bower, the starboard bower anchor and the best anchor in the ship.

The next days, from 6-16 February, potentially were of great interest, since they are the days when Charles Darwin was recording his important observations concerning Tasmania (Davies 2009). However, the log entries record only the merest outline of activities such as "harbour duties", or "employed variously on ship's duties'. On nearly every day the entry "received $69 \mathrm{lb}$ of fresh beef and veg." appears and one may speculate why this particular quantity was delivered each day. "Wood" is given on one day, presumably as fuel for the Cook. On Sunday 14 February at 10 am the crew was "mustered by divisions", for Divine Service, but at $5 \mathrm{pm}$ the topgallant yards were lowered; the work of the ship had to go on. On this day also, Darwin wrote to his sister Catherine to the effect that, "there never was a ship so full of homesick heroes as the Beagle" (Darwin 1836).

On Monday 15 February, the topgallant masts were reerected and the yards "crossed" on the following day. On this same day, 16 February 1836, Lieutenant Duff of the 21 st Regt. was embarked "for passage to England".

It is noteworthy that the Wind, Force, Weather, Sympiesometer, and Air Temperature readings were scrupulously observed for every day in harbour. The value of this information as a predictor of the future was probably in the captain's mind.

The 17 February 1836 began with the reception of $207 \mathrm{lb}$ of fresh beef and "vegls". The ship was then hove short on B.B., the Best Bower anchor. At 9 am anchor was weighed and all sail made to royals. The weather was still gloomy. The wind was variable and force 1 , and later, towards noon, passing showers fell. The wind was now northwesterly and variable, not atypical for Hobart. After noon (no sight), the ship was tacking in rising wind which was now southeasterly but still variable, required lowering royals and topgallants, first and second reefs were taken in topsails. The Iron Pot Lighthouse was passed at $2 \mathrm{pm}$, and reefs were taken out in failing wind. The course was now southeast and a bearing was made of Cape Raoul. At 11.15 pm the courses (main sails on both masts) were set and trysails taken in. The land was lost at $10.30 \mathrm{pm}$ in the darkness, the ship having made 20 miles or so to the seaward. Arthur Mellersh, Peter Benson Stewart and Edward Chaffers were the Officers (table 6, pl. 1). 
TABLE 4

Day Table of the log of H.M.S. Beagle for 4 February 1836

$\mathrm{H}=$ Hour; $\mathrm{K}=$ Speed in Knots; $\mathrm{S}=$ ? State of the sea or Swell; Course, measured in compass points, there being

32 in the complete "Boxing of the Compass"; $b=$ by; Wly = westerly: Wind Force measured by Admiral

Beaufort's Scale; Weather, recorded as Beaufort's weather Letters in FitzRoy 1839, pp. 40-41; q = squalls;

Sympiesometer = barometric pressure; Air Temperature in degrees Fahrenheit; Lee Sig = ? initials of the Officer of the Watch.

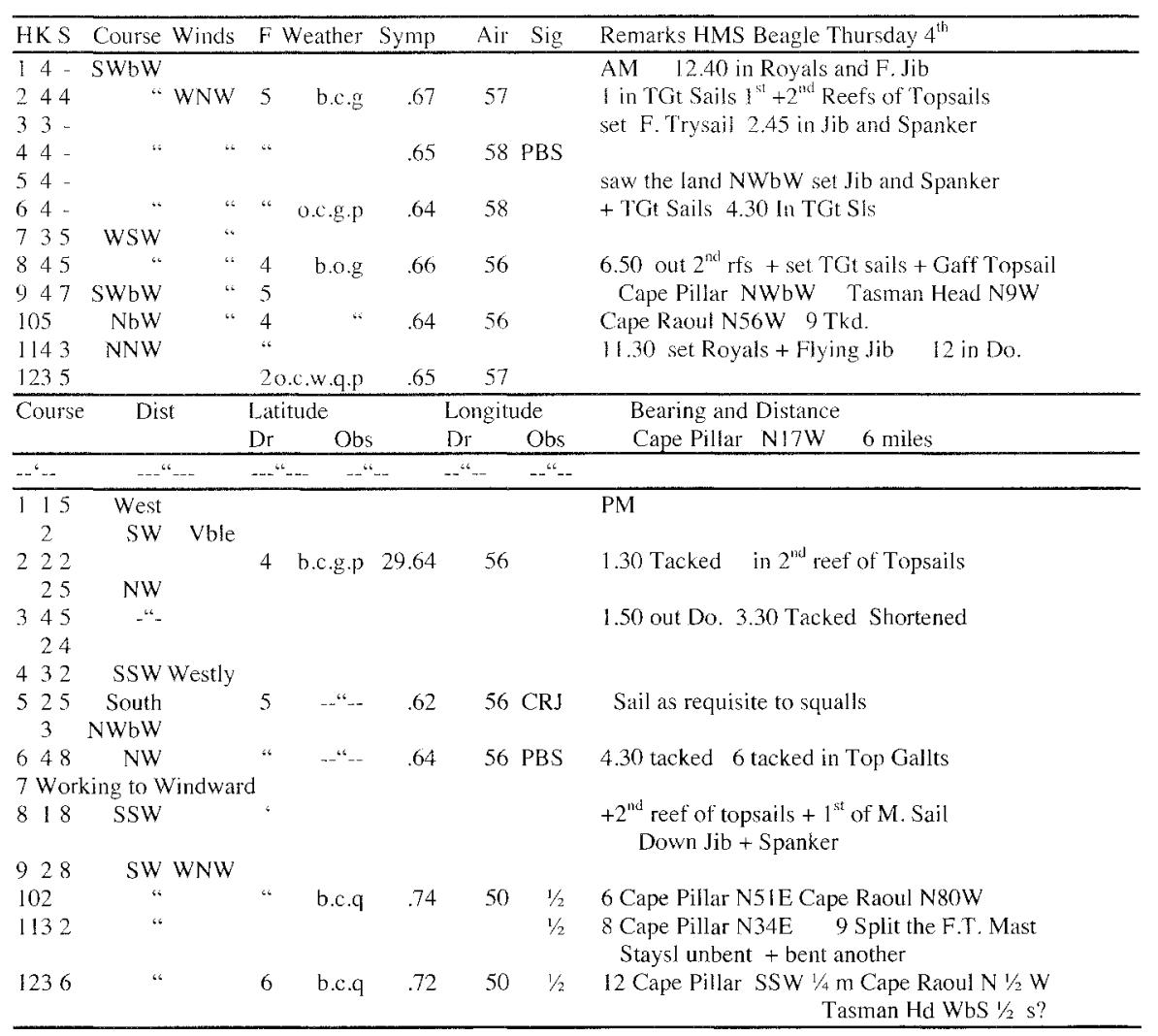

On 18 February, the ship was becalmed at 2 am, but the course was laid south before a fitful northerly and rising wind to become south by west by $7 \mathrm{am}$. All sail was made including studdingsails, and trimmed, and the course maintained, making 5-6 knots (table 7, pl. 1).

The noon sight gave a position and a bearing to an unidentified "Ruisck Rock", but the position suggests that this was Pedra Branca, $23 \mathrm{~km}$ off South East Cape. With the wind rising to 6 , the studdingsails were struck. The course was now west by south before a light northerly wind. Land was seen northwest by west to north northwest. There is high ground in Southwest Tasmania, and this would be visible at a distance of perhaps 50 miles. At $7.15 \mathrm{pm}$ "Peak to Sugar Loaf N25W" is recorded. A rough plot using known positions and recorded distances through the water shows this bearing passes through Federation Peak, a prominent point at $1224 \mathrm{~m}$. With the wind still light, studdingsails, royals and flying jib were set, the Beagle was making 5 knots, the course being still west by south.

On 19 February the course was maintained west by south, the wind was still light and variable from north to east. All day the sails were set and trimmed to try to get more speed. The weather was overcast, with rain and mist, and a noon sight was not possible, but a position was given by dead reckoning, estimating South West Cape S56W at 52 miles (table 8). This must surely be a mistake, as this would put the ship somewhere in the mountains of Western Tasmania. If the reciprocal bearing of N56E is accepted, then this puts the ship very close to the dead reckoning position. This mistake would hardly mean anything to the navigator on the ship, but looks very strange to a subsequent historian. The consolidated Course of S89W and the Day's Run confirm the true position.

In the afternoon, the course changed round as far as east with continuing dull rainy weather, but rising wind, to force 7 , required reefs to be put in, and the striking of royals. By $7 \mathrm{pm}$ the wind had gone to south so a course west by north was laid. A rising barometer was recorded.

By 20 February, southeast and variable winds enabled a course approximately northwest to be maintained and reefs were taken out in force 4 wind. Changing winds to northwesterly made tacking necessary, not usual at sea. A noon sight gave a position, with Point Hibbs estimated at N72E 105 miles. The course was changed to south-southwest in the face of northerly winds (table 9).

In the afternoon the wind at force 4 became squally, reefs were taken in topsails, and the weather remained gloomy and rainy, but the wind going to south-southwest made the sea state change to rough for a time.

With the wind from south-southwest on 21 February and the course nearly four points off at west by north, reefs were taken out and royals and flying jib were set. Even in light winds, 3-5 knots was attained at times. Mustering for Divine Service did not prevent the wind dropping to force 1-2 and variable, and a noon sight gave a position and a distance of 188 miles from Kings (sic) Island of 188 miles (table 10). 
TABLE 5

Day Table of the log of H.M.S. Beagle for 5,6 and 7 February 1836 derived from the second eopy of the log kept by the Master, Edward Chaffers

$\mathrm{H}=$ Hour; $\mathrm{K}=$ Speed in Knots; $\mathrm{S}=$ ? State of the sea or Swell; Course, measured in compass points, there being 32 in the complete "Boxing of the Compass"; $b=$ by; Wly = westerly; Wind Force measured by Admiral Beaufort's Scale; Weather, recorded as Beaufort's weather Letters in FitzRoy 1839, pp. 40-41; q = squalls; Sympiesometer = barometric pressure; Air Temperature in degrees Fahrenheit; Lee Sig = ? initials of the Office of the Watch.

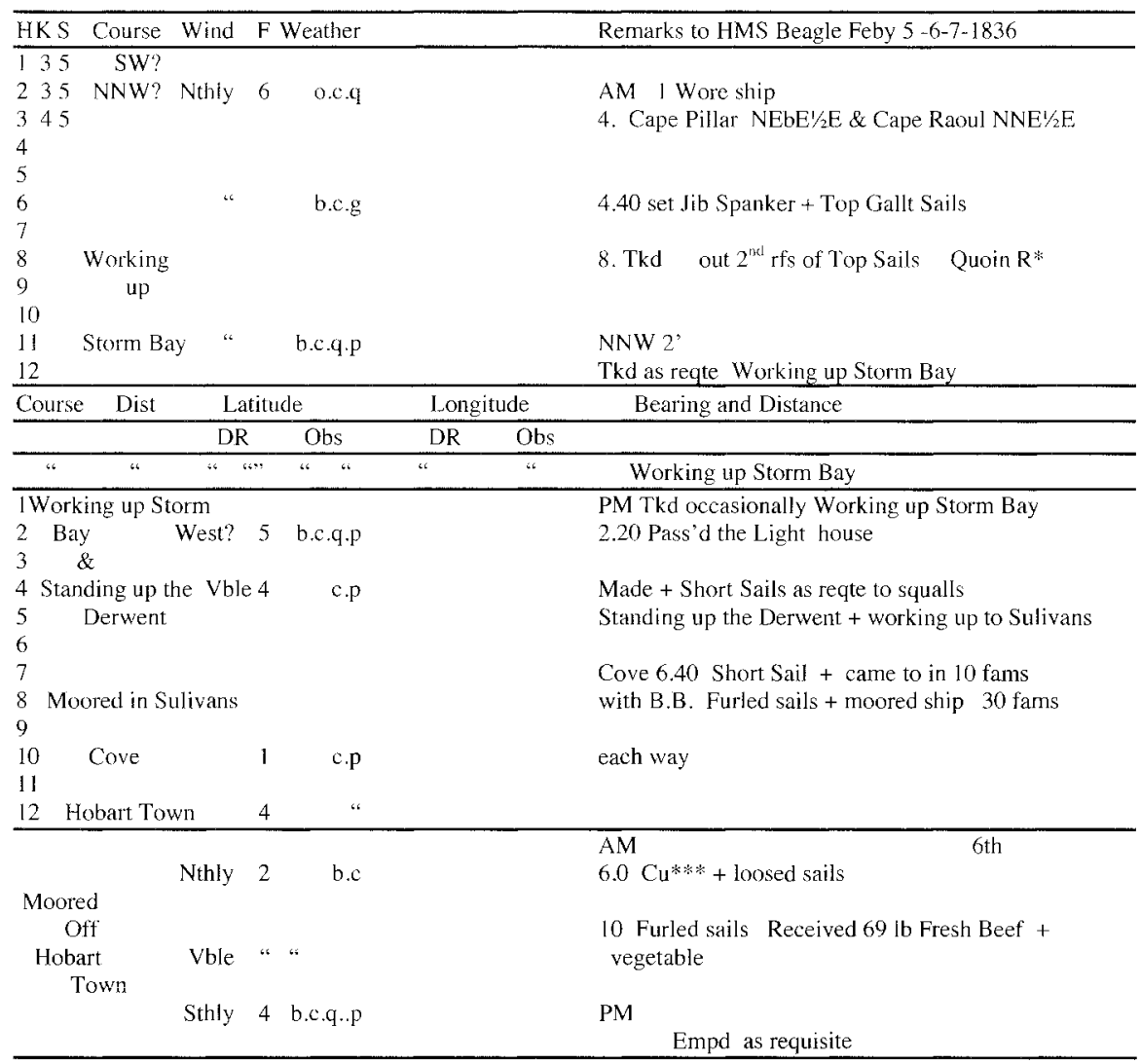

TABLE 6

Day Table of the log of H.M.S. Beagle for 17 February 1836

$\mathrm{H}=$ Hour; $\mathrm{K}=$ Speed in Knots; $\mathrm{S}=$ ? State of the sea or Swell; Course, measured in compass points, there being 32 in the complete "Boxing of the Compass"; $b=$ by; Wly = westerly; Wind Force measured by Admiral Beaufort's Scale; Weather, recorded as Beaufort's weather Letters in FitzRoy 1839, pp. 40-41; q = squalls; Sympiesometer $=$ barometric pressure; Air Temperature in degrees Fahrenheit; Lee Sig = ? initials of the Officer of the Watch.

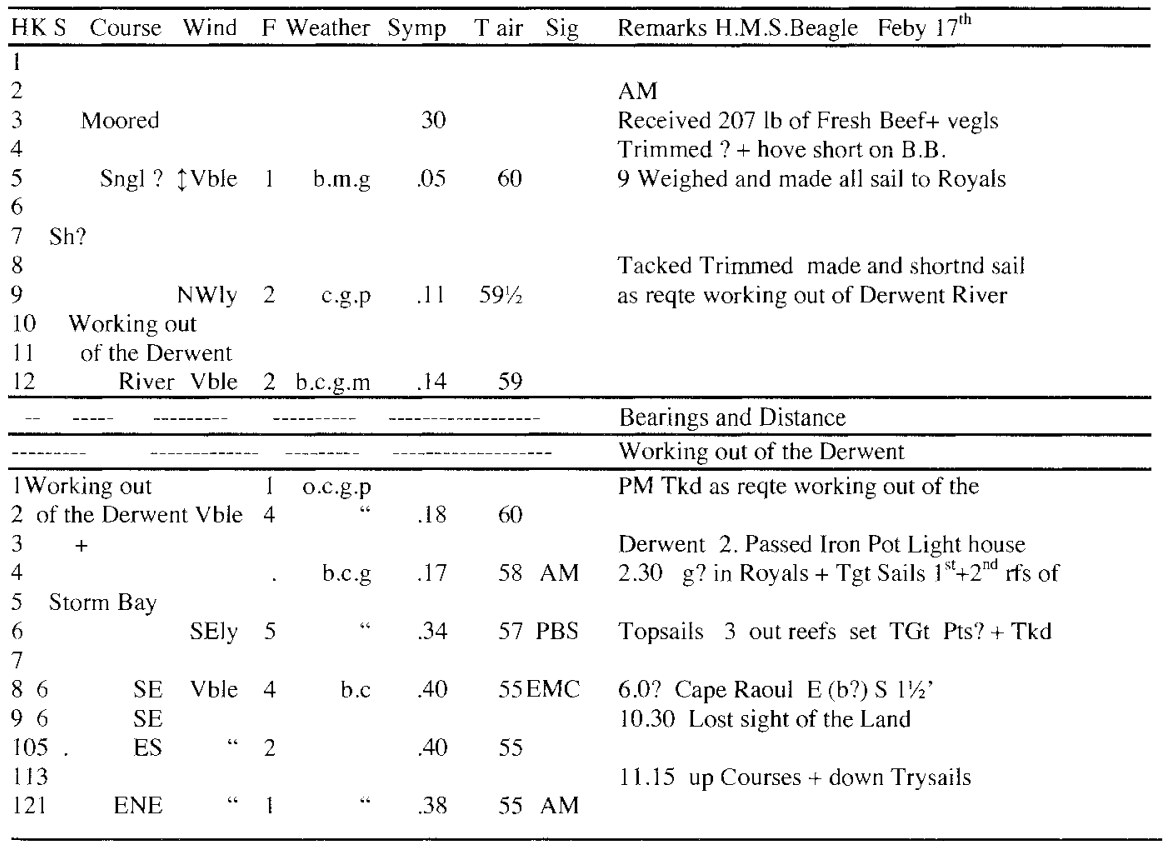


TARLE 7

Day Table of the log of H.M.S. Beagle for 18 February 1836

$\mathrm{H}=$ Hour: $\mathrm{K}=$ Speed in Knots; $\mathrm{S}=$ ? State of the sea or Swelf; Course, measured in compass points, there being 32 in the complete "Boxing of the Compass": $b=b y$; Wly = westerly; Wind Force measured by Admiral Beaufort's Scale; Weather, recorded as Beaufort's weather Letters in FitzRoy 1839, pp. 40-41; q = squafls; Sympiesometer = barometric pressure; Air Temperature in degrees Fahrenheit; Lee Sig = ? initials of the Officer of the Watch.

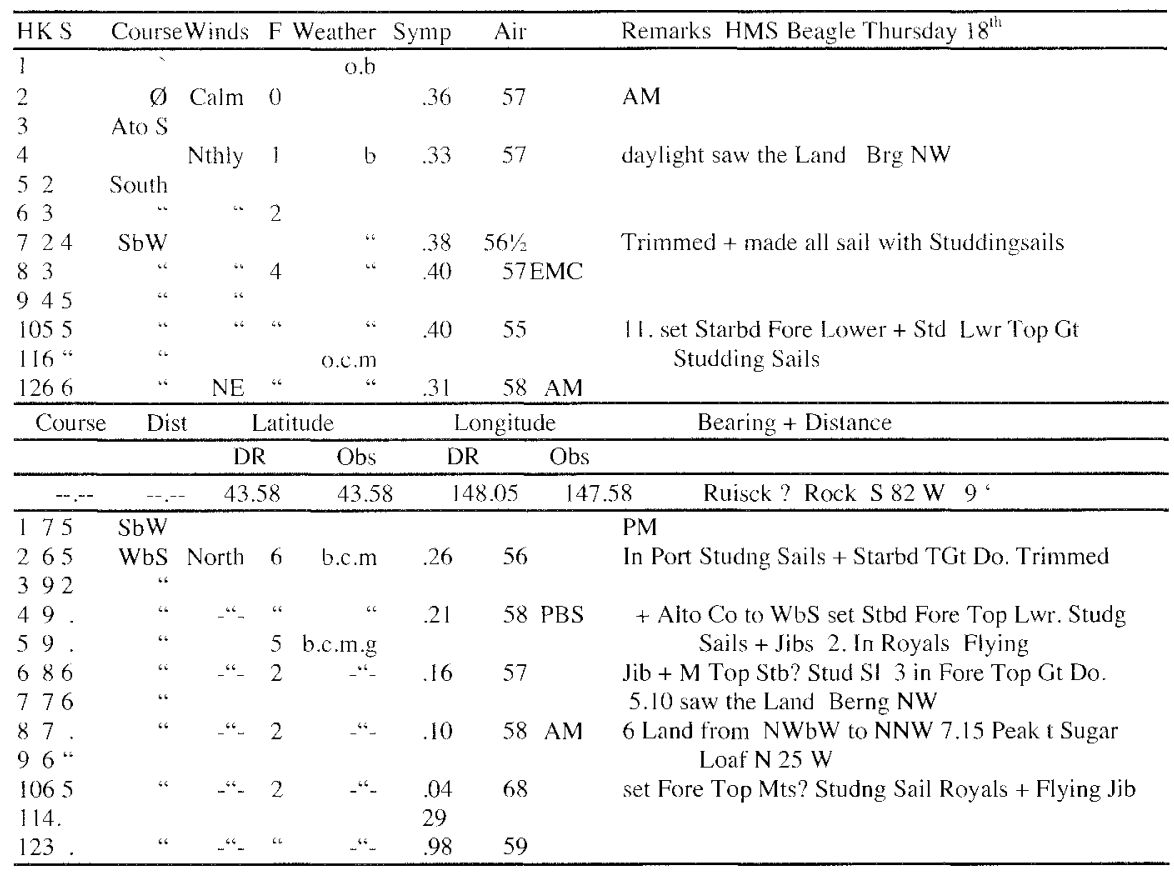

TABLE 8

Day Table of the log of H.M.S. Beagle for 19 February 1836

$\mathrm{H}=$ Hour; $\mathrm{K}=$ Speed in Knots; $\mathrm{S}=$ ? State of the sea or Swell; Course, measured in compass points, there being 32 in the complete "Boxing of the Compass"; $b=$ by; Wly = westerly; Wind Force measured by Admiral Beaufort's Scale; Weather, recorded as Beaufort's weather Letters in FitzRoy 1839, pp. 40-41; q = squalls; Sympiesometer $=$ barometric pressure; Air Temperature in degrees Fahrenheit; Lee Sig $=$ ? initials of the Officer of the Watch.

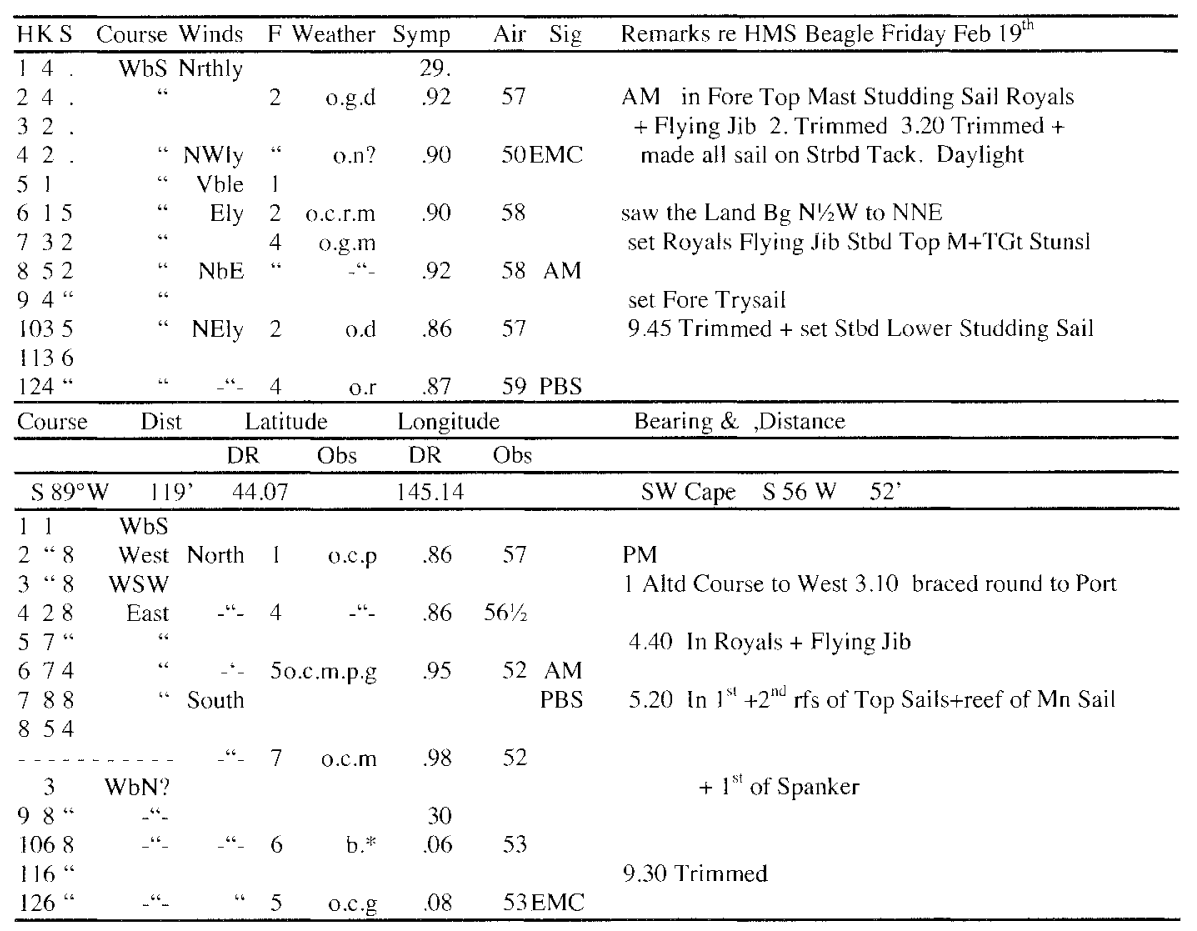


TABLE 9

Day Table of the log of H.M.S. Beagle for 20 February 1836

$\mathrm{H}=$ Hour; $\mathrm{K}=$ Speed in Knots; $\mathrm{S}=$ ? State of the sea or Swell; Course, measured in compass points, there being 32 in the complete "Boxing of the Compass"; $b=$ by; Wly = westerly; Wind Force measured by Admiral Beaufort's Scale; Weather, recorded as Beaufort's weather Letters in FitzRoy 1839, pp. 40-41; q = squalls; Sympiesometer $=$ barometric pressure; Air Temperature in degrees Fahrenheit: Lee Sig $=$ ? initials of the Officer of the Watch.

\begin{tabular}{|c|c|c|c|c|c|c|c|c|}
\hline HKS & Course & Winds & $\bar{F}$ & Weather & Symp & Air & Sig & Remarks re H.M.S. Beagle Saturday $20^{\text {th }}$ \\
\hline 158 & WNW & $\mathrm{SE}$ & & & & & & \\
\hline 248 & NWbW & & 5 & o.c.g & .08 & 52 & & $\mathrm{AM}$ \\
\hline 345 & NW & Vble & & & & & & \\
\hline 44 i & -"- & $\therefore-$ & " & $\therefore-$ & .08 & 52 & $\mathrm{AM}$ & 6 out $2^{\text {nd }}$ rf of Main Sail \\
\hline $55 *$ & NWbW & “ & & & & & & \\
\hline $\begin{array}{l}654 \\
75\end{array}$ & $-"-$ & $-“$ & 4 & “- & .08 & 54 & & 10 out $1^{\text {st }}$ reefs of Top Sails \\
\hline 857 & “- & N?NW & “ & -“- & .10 & 54 & & 10.20 Tacked \\
\hline $96 \%$ & NNW & & & & & & & \\
\hline $\begin{array}{c}1058 \\
2\end{array}$ & $\begin{array}{l}\mathrm{N} 1 / 2 \mathrm{~W} \\
\text { North }\end{array}$ & -6 & " & $\therefore$ & .12 & 55 & & \\
\hline $\begin{array}{l}1152 \\
125^{\prime \prime} \mathrm{S}\end{array}$ & $\begin{array}{r}S S W \\
S b W^{1} / 2 W \\
\end{array}$ & - & & b.a.p.g & 10 & 55 & & \\
\hline Course & Dist & Latitu & & & Longitude & & & Bearing + Distance \\
\hline & & DR & & Obs & DR & & $\mathrm{Obs}$ & \\
\hline N67W & 110 & 43.23 & & 43.03 & 142.55 & & 143.35 & Pt Hibbs $N 72^{\circ} \mathrm{E} \quad 105^{\circ}$ \\
\hline 148 & SWbS & & & & & & & PM \\
\hline $\begin{array}{lll}2 & 4 & 5 \\
3 & 4\end{array}$ & “ & NE? & 4 & o.c.q & .10 & 54 & & \\
\hline 44 " & “ & - "- & 4 & o.g.g & .07 & 54 & AM & \\
\hline $55^{\prime \prime}$ & “ & & & & & & & \\
\hline $65^{4}$ & “ & $-“$ & " & $-" *$ & .08 & 54 & & in $1^{\text {st }}$ reefs of Top Sails \\
\hline 74 & West & & & & & & & 6.45 Tacked \\
\hline 842 & “ & $\therefore$ & 4 & o.g.q.p & .14 & 54 & & \\
\hline 935 & $\because$ & & & & & & & \\
\hline 1038 & $\mathrm{WbN}$ & SSW & 4 & $-“$ & .15 & 57 & & \\
\hline 1144 & " & & & b.c.p & & & & \\
\hline 125 & " & 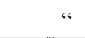 & $"$ & b.c & 20 & 57 & $\mathrm{AM}$ & \\
\hline
\end{tabular}

TABLE 10

Day Table of the log of H.M.S. Beagle for 21 February 1836

$\mathrm{H}=$ Hour; $\mathrm{K}=$ Speed in Knots; $\mathrm{S}=$ ? State of the sea or Swell; Course, measured in compass points, there being 32 in the complete "Boxing of the Compass"; $b=$ by; Wly = westerly; Wind Force measured by Admiral Beaufort's Scale; Weather, recorded as Beaufort's weather Letters in FitzRoy 1839, pp. 40-41; q = squalls; Sympiesometer = barometric pressure; Air Temperature in degrees Fahrenheit; Lee Sig $=$ ? initials of the Officer of the Watch.

\begin{tabular}{|c|c|c|c|c|c|c|c|c|}
\hline $\mathrm{HKS} \mathrm{C}$ & Course & Winds & & Weather & Symp & Air T & Sig & Remarks re HMS Beagle Sunday Feb $21^{\text {st }} 1836$ \\
\hline $15^{6}$ & $\mathrm{WbN}$ & SSW & 4 & b.c? & .16 & 52 & & AM \\
\hline $25 “$ & $"$ & & & & & & & \\
\hline $35 "$ & “ & & & & & & & 2. out $1^{\text {st }}$ reefs \\
\hline 452 & $"$ & -“- & " & $-"$. & .19 & 52 & & \\
\hline $55 "$ & $"$ & & & & & & & 6. set Royals + Flying Jib \\
\hline \multicolumn{9}{|l|}{64} \\
\hline$-\cdots$ & & & & & & & & \\
\hline 1 & WbS & & & & .28 & 51 & & \\
\hline 745 & 6 & & & & & & & \\
\hline $85 “$ & West & $-"$ & 2 & “ & .32 & $67 ?$ & EMC & 10.20 Mustered by Divisions \\
\hline 935 & NbW & & & & & & & \\
\hline $1035 Y$ & WNW & Vble & $"$ & $\therefore$ & .32 & 51 & & \\
\hline 1133 & $“$ & & & & & & & \\
\hline 1225 & “ & -“- & 1 & o.c & .3251 & & $\mathrm{AM}$ & \\
\hline \multirow[t]{2}{*}{ Course } & Dis & \multicolumn{3}{|c|}{ Latitude } & \multicolumn{2}{|l|}{ Longitude } & & Bearing + Distance \\
\hline & & DR & & Obs & DR & Obs & & \\
\hline $\mathrm{N} 88 \mathrm{~W}$ & 86 & 43.00 & & 42.55 & 141.37 & & $2.03 * *$ & Kings Is. Strd? N 25 E 188' \\
\hline 118 & West & SSW & & & & & & PM \\
\hline $23 "$ & $\mathrm{WbN}$ & Vble & 2 & b.c & .32 & 51 & & \\
\hline $32 ،$ & " a & & & & & & & \\
\hline 417 & West & -“ & 1 & -“- & .3252 & & PBS & \\
\hline 517 & & & & & & & & \\
\hline $62 ،$ & " & “. & $"$ & $-“$ & .43 & 55 & & 7. (o) set S $56^{\circ} 50^{\prime} \mathrm{W}$ \\
\hline $72 ،$ & “ & SSE & & & & & & 7.15 Trimmed + set Port TGt Studd Sl*? \\
\hline 828 & “ & -4 & 2 & $-"-$ & .34 & 52 & AM & Fore Top Mast Studding Sails down F Trysail \\
\hline 925 & “ & & & & & & & 9.30 Trimmed down Trysails + Spanker \\
\hline 1025 & $“$ & $-“$ & 1 & $-“$ & .30 & 53 & & set Fore Course + Top mast Studdng Sls \\
\hline $112 “$ & $"$ & & & & & & & down Jib \\
\hline 1222 & « & SEly & $"$ & $-“$ & .30 & 53 & & \\
\hline
\end{tabular}


TABLE 11

Day Table of the $\log$ of H.M.S. Beagle for 22 February 1836

$\mathrm{H}=$ Hour; $\mathrm{K}=$ Speed in Knots; $\mathrm{S}=$ ? State of the sea or Swell; Course, measured in compass points, there being 32 in the complete "Boxing of the Compass"; $b=$ by; Wly = westerly; Wind Force measured by Admiral Beaufort's Scale; Weather, recorded as Beaufort's weather Letters in FitzRoy 1839, pp. 40-41; q = squalls; Sympiesometer = barometric pressure; Air Temperature in degrees Fahrenheit; Lee Sig = ? initials of the Officer of the Watch.

\begin{tabular}{|c|c|c|c|c|c|c|c|c|}
\hline \multirow{2}{*}{$\frac{\mathrm{HKS}}{13^{\circ}}$} & \multirow{2}{*}{$\frac{\text { Course }}{\text { West }}$} & Winds & \multicolumn{2}{|c|}{ F Weather } & \multicolumn{3}{|c|}{ SympThrm AirSig } & \multirow[t]{2}{*}{ Remarks re HMS Beagle Monday $22^{\text {nd }}$} \\
\hline & & & & & & & & \\
\hline 234 & & Eastly & 2 & b. & .32 & 51 & & $\mathrm{AM}$ \\
\hline $33^{\prime \prime}$ & & & & & & & & 3. Trimned Sails \\
\hline $43^{\prime \prime}$ & “ & -“- & “ & - - & .325 & & EMC & $5.35(\mathrm{o})$ rose $\mathrm{S} 83^{\circ} \mathrm{E}$ \\
\hline 538 & $"$ & & & & & & & \\
\hline 645 & “ & -“- & 2 & -“" & .37 & $51 ?$ & & 6.20 set Stbd Fore Course + Stbd? Top Mst \\
\hline 745 & & & & & & & & Studng Sails up Mn Sail \\
\hline 847 & “ & $-4-$ & & "b.c & .41 & 52 & $\mathrm{AM}$ & 9.30 Shifted ? over Studding Sails \\
\hline 958 & & & & & & & & \\
\hline $106 "$ & “ & -“ & 4 & - & .37 & 54 & & \\
\hline 1166 & “ & & & & & & & \\
\hline 1268 & _“- & ENE & 4 & $-c-$ & .34 & 54 & PBS & \\
\hline \multirow[t]{2}{*}{ Course } & Dist & & \multicolumn{2}{|c|}{ Latitude } & \multicolumn{2}{|c|}{ Longitude } & & Bearing + Distance \\
\hline & & \multicolumn{2}{|c|}{ DR } & Obs & \multicolumn{2}{|c|}{$\mathrm{DR}$} & Obs & \\
\hline W 81 & $81^{\prime}$ & \multicolumn{2}{|c|}{42.40} & 42.29 & \multicolumn{2}{|c|}{139.53} & 139.48 & Kings Is. Str? N51 E-230' \\
\hline 168 & West & & & & & & & PM \\
\hline 275 & “ & ENE & 4 & b.c & .30 & 55 & & \\
\hline $38 "$ & & & & & & & & \\
\hline 475 & “ & $-“$ & 4 & $\therefore$ & .29 & 55 & & \\
\hline 575 & “ & & & & & & & 7.30 Carried away Stbd Main Top Mt. \\
\hline 676 & “ & $-“$ & $“$ & -"“- & .26 & 54 & $\mathrm{AM}$ & Studg Sail Boom In all Studding Sails \\
\hline 788 & “ & & & & & & & \\
\hline 892 & & $-"$ & 7 & b.c.m & .18 & 55 & PBS & + Royals \\
\hline 984 & " & & & & & & & \\
\hline 108 “ & “ & & & -“- & .22 & 55 & & 9 Trimmed \\
\hline 1185 & “ & & & & & & & \\
\hline 1283 & “ & $-“-$ & 5 & o.g.m & .11 & 55 & EMC & \\
\hline
\end{tabular}

At $7 \mathrm{pm}$ an Amplitude observation of the sunset gave a true bearing of $S 56^{\circ} 50 \mathrm{~W}$ to enable magnetic bearings to be corrected. Winds remained light but southeasterly and sail changes tried to get the best out of force 1 and 2 . The weather was clearer with blue sky and clouds.

A course to the west was held on 22 February with winds easterly and slowly rising. The weather remained fair (table 11). Another Amplitude observation of sunrise gave a true bearing of $S 83^{\circ} \mathrm{E}$. Sails were set in force $2-4$ winds. A noon sight gave a position and a distance from King Island of 230 miles at N51E. At $7.30 \mathrm{pm}$ rising wind carried away the starboard main topmast studdingsail boom, prompting all studdingsails and royals to be struck and the ship was now making 7 or 8 knots with a following wind.

\section{DISCUSSION}

From these interpreted remarks, one is constantly made aware of the complete reliance of the voyage on the wind and the weather, and the constant demands of the crew to go aloft night and day to handle the sails. There is a sense that the crew was trying to hurry the ship along, but taking care to respond carefully to squalls.

\section{Sail handling}

Sail handling on such a vessel as Beagle is very much the creature of the wind and intended course directions. It is instructive to compare these two directions on a compass rose (a circular diagram representing the 32 "compass" points radially). This reveals the extent to which the ship is "close- hauled", that is, how much she is made to sail into the wind. The changes made to the rig before the ship left England, namely the addition of a mizzen mast and a spanker sail enabled her, together with the carrying of inner and outer jibs and staysails, to be sailed to some extent as a "fore and aft" vessel. She would then be able to sail closer to the wind and be more controllable in difficult conditions. The fore and aft sails would also require much less manpower and would also be safer, as the crew would not need to go aloft, as square sails would require.

The urgency of the return to England is evident from the frequent use of studdingsails, additional sails set out on either side of the square sails. Just a few more miles in the day made the extra effort and risk worthwhile. At the same time prudent first and second reefs are taken, it is not worth taking too much risk and losing the ship towards the end of the voyage.

For example, on 3 February 1836 at 5 am the ship was taken aback, that is, a change of wind fell on the forward sides of the square sails, a distressing situation. A course change gave some relief, and ultimately wearing ship, that is, changing tack by turning away from the wind, did not prevent it happening again at $9.15 \mathrm{am}$. Finally the wind resolved itself and serene sailing resumed. By the afternoon, staysails, trysails, and spanker and gaff topsails were all in use, that is, all fore and aft sails.

Late on 4 February, in the dark, when south of capes Raoul and Pillar, the fore topmast staysail was blown out and had to be replaced. After more than four years at sea, it is unlikely that any sails were new. 


\section{The weather situation}

The weather during the Tasmanian part of the voyage is given in the Meteorological Observations in Volume II of FitzRoy (1839). The entries correspond well, but there is more immediate detail in the log.

Ian Barnes-Keoghan of the Hobart Office of the Bureau of Meteorology (pers. comm.) comments as follows:

"6-17 February 1836, Hobart Town

The reported weather through this time seems not atypical of a Hobart February: temperature in the (degrees Celsius) teens, generally "fine" weather, but with a cold front.

On Beagle's arrival in Hobart, the winds are light and variable, weather clear (though with some cloud), and the pressure moderately high (as would be expected with a high pressure system nearby), temperature 10 or $11^{\circ} \mathrm{C}$ (although these are mostly taken at $9 \mathrm{am}$, so such low temperatures are reasonable).

There appears to have been a cold front crossing between $4 \mathrm{pm}$ and $9 \mathrm{pm}$ on 14 February. The $4 \mathrm{pm}$ temperature was $24^{\circ} \mathrm{C}$, with the wind strengthening (and squally) north to northwesterly (it reaches force 7 ), and the barometer falling steadily. By $9 \mathrm{pm}$ the wind has shifted southeasterly, and lightning is reported. The next morning finds the temperature around $13^{\circ} \mathrm{C}$ and the weather "gloomy". The reports do not make any mention of rain during the period, although it is possible this fell at other than an observation time."

An examination of the weather reports of the entire 22 days of the record enables some other comments to be made. The abrupt change of temperature, the squall indication, the "gloomy" remark, and reefing at $5 \mathrm{pm}$ on 1 February seem to indicate the passage of a cold front. High barometer and more "gloomy" comments on the following day may represent a summer-time high, as does the change of wind to the south-southwest.

Variable winds on 3 February, which require some complex manoeuvres attended by squalls, precede the re-establishment of northerly winds late in the day. On 4 February blue skies and at the same time overcast and gloomy weather are recorded, and may perhaps indicate mountain waves in the wake of the Tasmanian mountains. Squally weather on 5 February may be indicative of the sudden gusts experienced close to the Tasmanian mountain coasts.

Taking up the story on 17 February, light northerly winds and a change to southeasterly hampered progress to the seaward from the Derwent, and on 18 February a calm sea presaged a rising northerly, accompanied by a falling barometer. This continued to fall on 19 February with variable and easterly winds, enabling quicker progress to be made at the end of the day. A late rise in the glass and another change of wind from east to north and then south must have made the crew wish for the open sea and more consistent winds.

This wish was not fulfilled on 20 or 21 February with more continuing light and variable winds, squalls again indicated, and the ship clawing to the northward. But on 22 February the easterlies improved, and better progress was made, even to the extent that a studdingsail boom was carried away as the ship set course for King George's Sound in Western Australia.

There appears from the density of weather information that synoptic situations could be derived from it, but this remains to be attempted.

\section{An unanswered question}

While in Hobart, Captain FitzRoy wrote (FitzRoy 1839 , p. 624):

"During a few days stay in Sullivans Cove, the chief anchorage, we had opportunities of going some distance into the country, and seeing things which led me to think that there is a more solid foundation for future prosperity in Van Dieman's Land than can be found in Sydney. Natural advantages are greater; and likely to increase as the land is cleared and inhabited - because rain is now almost too plentiful, though corn ripens well and is of excellent quality."

David Leaman (per. comm.), who has followed Darwin's movements in Tasmania very closely (Banks \& Leaman 1999), notes that Darwin was appointed to be companion to FitzRoy and speculates that during the second week of their stay, Darwin was free to do much as he liked and was not required to attend dinner with the captain. Indeed, he came in late, or ate out. These actions may mark the days of FitzRoy's absence. Given the few comments made by FitzRoy about midland Tasmania and his aristocratic connections it seems likely that he visited, or was invited to stay with, the local members of upper class Tasmania in the region between Connorville and Fingal in northern Tasmania.

Where did be go, and who did he see? My enquiries have revealed no answer so far.

\section{ACKNOWLEDGEMENTS}

Thanks are due to the following: Prof. Michael Roe, for encouragement and the loan of the Master's Log; Rob Thomas, of the sail training ship Lady Nelson, for discussion of sail handling; Ian Barnes-Keoghan, for his contribution on the weather; June Pongratz, for producing the illustrations and Dr Margaret Davies, for her enthusiastic encouragement.

\section{REFERENCES}

Banks, M.R. \& Leaman, D.E. 1999: Charles Darwin's field notes on the Geology of Hobart Town - a modern appraisal. Papers and Proceedings of the Royal Society of Tasmania 133: 29-50.

Darwin, C.R. 1836: Letter to his Sister Catherine. Letter 298, 14 th Feb 1836, Darwin Correspondence Project.

Darwin, C.R. 1839a: Journal and Remarks, 1832-1836, Volume III in FitzRoy, R (ed.): Narrative of the Surveying Voyages of His Majesty's Ships Adventure and Beagle between the years 1826 and 1836, describing their examination of the southern shores of South America, and the Beagle's circumnavigation of the globe. Wordsworth Editions, London: $352 \mathrm{pp}$.

Darwin, C.R. 1839b: Journal of Researches into the Natural History and Geology of the Countries visited during the Voyage round the World of H.M.S. Beagle under the command of Captain FitzRoy R.N., 2nd edn., Henry Colburn, London: 727 pp.

Davies, M. 2009 (ed.): Charles Darwin in Hobart Town. The Royal Society of Tasmania, Hobart: $124 \mathrm{pp}$.

FitzRoy, R. (ed.) 1839: Narrative of the Surveying Voyages of His Majesty's Ships Adventure and Beagle between the Years 1826 and 1836, Describing their Examination of the Southern Shores of South America, and the Beagle's Circumnavigation of the Globe. 3 vols and appendix to Volume II. Henry Colburn, London: $2862 \mathrm{pp}, 46 \mathrm{pls}$.

Geddie, W. 1959: Chamber's Twentieth Century Dictionary. W \& R. Chambers Ltd, London \& Edinburgh: 1837 pp.

Norie, J.W. 1943: Norie's Nautical Tables. Imray, Laurie, Norie \& Wilson, London: 735 pp.

(accepted 3 November 2009) 